\title{
Die Septuaginta - Text, Wirkung, Rezeption
}

\author{
4. Internationale Fachtagung veranstaltet von Septuaginta Deutsch (LXX.D), \\ Wuppertal 19.-22. Juli 2012 \\ Hrsg. v. Wolfgang Kraus u. Siegfried Kreuzer in Verb. m. Martin Meiser u. Marcus \\ Sigismund
}

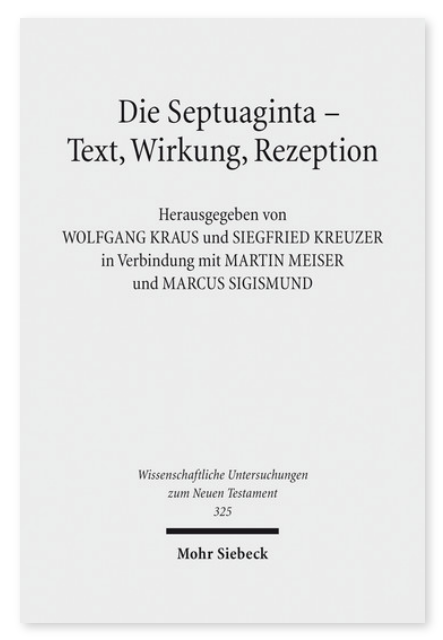

2014. XIV, 928 Seiten. WUNT I 325

ISBN 978-3-16-152890-3

DOI 10.1628/978-3-16-152890-3

eBook PDF $244,00 €$

ISBN 978-3-16-152653-4

Leinen $244,00 €$
Die Septuaginta ist als jüdische Bibelübersetzung ab dem 3. Jh. v. Chr. entstanden. Sie wurde zur zentralen Grundlage des Judentums in der griechisch-hellenistischen Welt und in weiterer Folge für die Verbreitung des Christentums. Sie wurde von den meisten neutestamentlichen Autoren als Grundlage ihrer Schriftzitate benutzt und ist das Alte Testament in den orthodoxen Kirchen. Zudem gibt sie Einblick in das Schriftverständnis und die Theologie des Griechisch sprechenden Judentums in der Antike. In textgeschichtlicher Hinsicht ist sie die wichtigste Quelle neben dem hebräisch-masoretischen Text, zumal sie, anders als die biblischen Texte aus Qumran, vollständig überliefert ist. Die Septuaginta-Forschung bildet einen eigenständigen Bereich neben der Erforschung der hebräischen Bibel und liegt im Schnittfeld mit dem Neuen Testament und mit antiker Geschichte und Religionsgeschichte.

Der vorliegende Band enthält Studien zum Text und zur Textgeschichte der Septuaginta, zu ihrer Philologie und Geographie sowie zur Theologie und zur Rezeptionsgeschichte. Er gibt einen Überblick über den gegenwärtigen Forschungsstand und zeigt Perspektiven für die weitere Forschung auf. Der Band ist erwachsen aus einer internationalen Tagung des Projektes Septuaginta Deutsch, die im Juli 2012 in Wuppertal stattfand.

Inhaltsübersicht

Allgemeines

Wolfgang Kraus: Die hermeneutische Relevanz der Septuaginta für eine Biblische Theologie Gilles Dorival: The Septuagint Between Judaism and Hellenism

\section{Textgeschichte}

Adrian Schenker: Abraham Geigers Auffassung von der alttestamentlichen Textgeschichte und die alte griechische Bibel im Licht von 1 Kön 15,15 - Julio Trebolle: The Textual History and the Text-Critical Value of the Old Latin Version in the Book of Judges - Siegfried Kreuzer: Älteste Septuaginta und hebraisierende Bearbeitung. Old Greek und Semi-kaige im nicht-kaigeText von 2Samuel (mit einer Analyse von 2Sam 4,1-5) - Benjamin G. Wright III: Preliminary Thoughts about Preparing the Text of Ben Sira for a Commentary - Felix Albrecht: Zur Notwendigkeit einer Neuedition der Psalmen Salomos

Martin Karrer/Johannes de Vries: Der Septuagintatext in den neutestamentlichen Schriften und der Codex Ambrosianus Alison Salvesen: Aquila, Symmachus and the Translation of Proof-texts

\section{Geographie}

Michaël N. van der Meer: Syria in the Septuagint. Studies in the Natural and Geographical Context of the Septuagint

Philologie

Valérie Kabergs: Puns within the Context of Name Explanations in MT and LXX Exodus - Takamitsu Muraoka: Syntax of the Infinitive in the Septuagint Book of 2Samuel: Kaige and Antiochene Texts Compared - Jean-Marie Auwers/Bastien Kindt: Tobie et Esther dans le Thesaurus duplex Septuaginta

Dirk Büchner: Brief Remarks on the Occurrence and Value of Blood in Greek Sources from Epic Literature to Early Christianity - Philippe Le Moigne: La virgule de Cléopâtre ou Considérations sur l'emploi de la ponctuation, avec une attention plus particulièrement portée à la virgule, dans les éditions Tischendorf, Swete, Rahlfs et Ziegler d'Ésaïe-LXX: usages éditoriaux, choix interprétatifs, enjeux poétiques

\section{Theologie}

Christian Eberhart: Beobachtungen zu Opfer, Kult und Sühne in der Septuaginta - Emanue/ Tov: The Harmonizing Character of the Septuagint of Genesis 1-11 - Arie van der Kooij: The Old Greek of Isaiah 9,6-7 and the Concept of Leadership - Jan Joosten: The Samareitikon and the Samaritan Tradition

\section{Rezeption}

Frühjudentum

Gert J. Steyn: Reflections on the Reception of the LXX Pentateuch in Philo's De Vita Mosis - William Loader: Genesis 3,16-19 LXX in Reception: Observations on its Use in Early Judaism and Christianity to ca 100 CE - Beate Ego: Die Theologisierung der Estererzählung - Von der Septuaginta zu Targum Scheni - Ralph Brucker: »Wer ist der König der Herrlichkeit?« Ps 23[24] Text, Wirkung, Rezeption

Eberhard Bons: Psalter Terminology in Joseph and Aseneth - Gideon R. Kotzé: Text-Critical and Interpretive Comments on Differences between the Greek and Hebrew Wordings of Lamentations 5

Barbara Schmitz: Die Juditerzählung - eine Rezeption von Dan 3LXX? - Martin Vahrenhorst: Zwischen Alexandria und 
Tiberias - Berührungen zwischen dem Text der LXX und rabbinischen Traditionen - Daniela Scialabba: The Vocabulary of Conversion in Joseph and Aseneth and in the Acts of the Apostles

Neues Testament

Martin Meiser: Die Funktion der Septuaginta-Zitate im Markusevangelium - Reinhard Feldmeier: »Der Höchste«. Das Gottesprädikat Hypsistos in der paganen Religiosität, in der Septuaginta und im lukanischen Doppelwerk - Florian Wilk: »Zu unserer Belehrung geschrieben...« (Römer 15,4): Die Septuaginta als Lehrbuch für Paulus - Dietrich-Alex Koch: Die Septuaginta in der Korintherkorrespondenz des Paulus - Bruce Chilton: The Curse of the Law and the Blessing of Atonement: Paul's Deployment of Septuagintal Language

Patristik

Mogens Müller: Die Septuaginta als Bibeltext der ältesten Kirche Graeca veritas contra Hebraica veritas - John Granger Cook: A Crucified Christ in the Septuagint? A Pagan Philosopher's Assault on the Foundations of the Septuagint and the New Testament - Armin Lange: The Canonical History of the Hebrew Bible and the Christian Old Testament in Light of Egyptian Judaism - Heinz Josef Fabry: Die Kanongeschichte der Hebräischen Bibel und des christlichen Alten Testamentes im Licht der Kirchenväter - Bonifatia Gesche: Die Vetus Latina-Version des Buches Jesus Sirach als Zeuge für die Version Griechisch II -

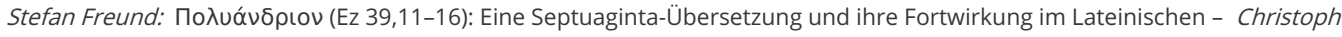
Schubert: Spuren (un?)mittelbarer Rezeption des LXX-Textes bei Ambrosius von Mailand - Eva Schulz-Flügel: Hieronymus Gottes Wort: Septuaginta oder hebraica Veritas - Cilliers Breytenbach: The Early Christians and Their Greek Bible: Quotations from the Psalms and Isaiah in Inscriptions from Asia Minor - Antonio Enrico Felle: Expressions of Hope Quoted for Biblical Texts in Christian Funerary Inscriptions (3rd-7th cent. C.E.) - Thomas Kraus: Außertextliche Rezeption von Ps 90. »Lebensgeschichte« und Lebendigkeit eines Psalms

Mariachiara Fincati: »Hebraiká« und »loudaiká« in mittelalterlichen biblischen Handschriften

Wolfgang Kraus Born 1955; 1990 doctorate; 1994 Habilitation; Professor emeritus for New Testament Studies at the University of the Saarland, Saarbruecken.

Siegfried Kreuzer Geboren 1949; Promotion und Habilitation in Ev. Theologie; 1991-2015 Professor für Altes Testament an der Kirchlichen Hochschule in Wuppertal; seit 1999 Mitwirkung bei Septuaginta Deutsch und am Institut für Septuaginta und Biblische Textforschung.

Martin Meiser Born 1957; 1983-91 Lutheran minister in Bavaria; 1991-2001 Assistant for New Testament in Erlangen; 200105 Assistant for Early Church History in Mainz; 2005-07 Vicarious Professor in Münster/Westphalia; since 2007 Associate Professor in Saarbrücken.

Marcus Sigismund Geboren 1971; 2002 Dr. phil.; seit 1999 Lehrbeauftragter an der Bergischen Universität Wuppertal; seit 2007 Wissenschaftlicher Mitarbeiter am Institut für Septuaginta und biblische Textforschung, seit 2022 Koordinator der UniService Digitalisierung der Lehre an der Bergischen Universität Wuppertal.

https://orcid.org/0000-0002-9345-767X

Jetzt bestellen:

https://mohrsiebeck.com/buch/die-septuaginta-text-wirkung-rezeption-9783161528903?no_cache=1

order@mohrsiebeck.com

Telefon: $+49(0) 7071-923-17$

Telefax: $+49(0) 7071-51104$

Mohr Siebeck GmbH \& Co. KG

Postfach 2040

D-72010 Tübingen

info@mohrsiebeck.com

Mohr Siebeck

www.mohrsiebeck.com 